
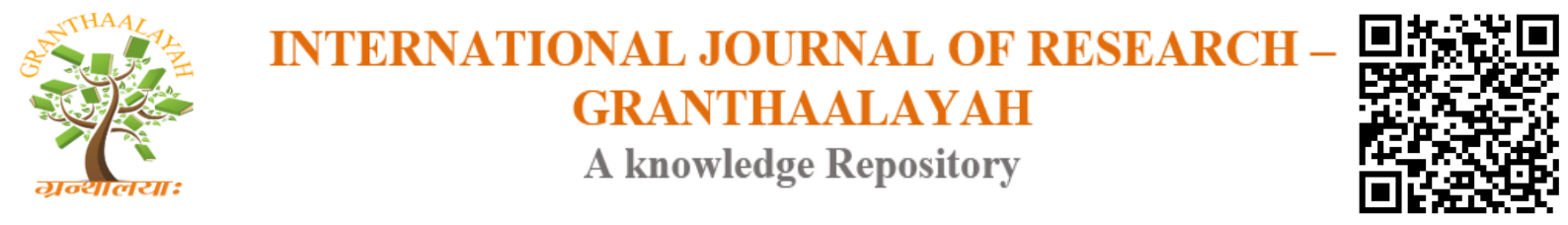

Management

\title{
A STUDY ON JOB SATISFACTION OF BANK EMPLOYEES (WITH SPECIAL REFERENCE TO INDIAN BANK-VELLORE CITY)
}

\author{
Mrs. C. Sumitha ${ }^{1}$, Dr.R.Padmaja ${ }^{2}$ \\ ${ }^{1}$ M.Com., SET., M.Phil., Assistant Professor, D.K.M. College for Women, Vellore-1, India \\ ${ }^{2}$ Associate Professor \& Research Supervisor, D.K.M College for Women (Autonomous), \\ Vellore - 632 001, India
}

\begin{abstract}
The study of job satisfaction among Bank employees is important because there are various aspects of the job that are highly attractive and lead to satisfaction and aspects of the job that lead to dissatisfaction. Positive aspects include the opportunity to work in Bank and employees to accomplish common goals, developing banking background and the ability to work with coworkers. It is important to identify which factors contribute to job satisfaction as well as those that may lead to job dissatisfaction to assure that the manager ship is attractive to potent. There are many variables that have been hypothesized to be a result of job satisfaction or dissatisfaction.

It is an established fact that the success of any organization depends on the satisfaction of its work force. The aim of this study is to determine that bank employees are satisfied with their job and also to identify those factors that are of high concern to bank employees regarding their satisfaction.
\end{abstract}

Keywords: Job Satisfaction; Bank Employees; Work Environment; Promotion.

Cite This Article: Mrs. C. Sumitha, and Dr.R.Padmaja. (2017). "A STUDY ON JOB SATISFACTION OF BANK EMPLOYEES (WITH SPECIAL REFERENCE TO INDIAN BANK-VELLORE CITY)." International Journal of Research - Granthaalayah, 5(7:SE), 12-23. https://doi.org/10.29121/granthaalayah.v5.i7(SE).2017.2038.

\section{Introduction}

Human life has become very complex and completed in now-a-days. In modern society the needs and requirements of the people are ever increasing and ever changing. In this era of competitive world, success of any organization depends on its human resource. Banks are no exception to this. The employees of the Bank are valuable assets to the organization. If they are highly satisfied they produce more and it is profitable for the organization. So in this competitive environment it is necessary to know the employees views toward their job and to measure the level of satisfaction with various aspects job satisfaction. Efficient human resource management and maintaining higher job satisfaction level in banks determine not only the performance of the 
bank but also affect the growth and performance of the entire economy. So, for the success of banking it is very important to manage human resource effectively and to find whether its employees are satisfied or not only if they are satisfied, they will work with commitment and project a positive image of the organization. If they are highly satisfied they produce more and it is profitable for the organization.

Job satisfaction is a general attitude towards one's job, the difference between the amount of reward workers receive and the amount they believe should receive. Employee is a back bone of every organization, without employee no work can be done. So employee's satisfaction is very important. Employees will be more satisfied if they get what they expected, job satisfaction relates to inner feelings of workers.

\section{Objective of the Study}

- To study the job satisfaction of employees in relation to working conditions.

- To analyze the job satisfaction of employees in relation to promotion.

- To identify and suggest some measures for improving the satisfaction level of the bank employees.

\section{Need and Scope of the Study}

From the literature reviewed the lacuna was identified that promotion and work environment plays a vital role for job satisfaction of the employees. The present study is focused on the analysing the Job Satisfaction of Bank Employees whose Work Culture is different to other type of employees. This study also aimed to analyse the various factors which positively impact the job satisfaction of employees. The study can be further extended to educational institutions also.

\section{Limitations of the Study}

1) This research was conducted in a limited area.

2) The sample size was confined only to 50 respondents.

3) Satisfaction level to environment factor may differ from person to person.

4) Measuring human attributes is complex.

\section{Meaning}

Job satisfaction means an extent of positive feelings or attitudes that individuals have towards their jobs. When a person says that he has high job satisfaction, it means that he really likes his job, feels good about it and values his job dignity.

\section{Definition}

Hoppack introduced the term "job satisfaction" in 1953 in his book on job-satsfaction. Hoppack defined job satisfaction as "Any combination of psychological, physiological and environmental circumstances that make a person say I am satisfied with the job" 


\section{Factors Determining Job Satisfaction}

\section{- Compensation/salary}

Compensation can be defined as the monetary benefit given to the employees by the company for their services given to the company.

\section{- Supervisor support}

It is one of the important factors for employee retention. It is defined as the extent to which leaders care about their employee's welfare and value their contributions. A leader with high supervisor support is one that makes employees feel appreciated, heard and cared about.

\section{- Working environment}

The working conditions include office space, equipments, comfortable chairs, air conditioning, tools etc. when working environment is good for an employee, then his/her productivity level automatically goes up.

\section{- Job security}

Job security is the chance that a person or an employee will keep his or her job; a person with the job would have a little possibility of becoming unemployed if his/ her job has an elevated level of job satisfaction.

\section{- Employee empowerment}

Empowerment involves giving employees the autonomy to make decisions they go about their daily activities so empowerment enhances the motivation of employees to go through their goals grooming their performances that satisfaction regarding their jobs.

\section{- Promotional policies}

Fair promotional policies in any organization become their foundation of growth. When an employee gets fair promotion, which is generally based on is generally based on his true assessment, he gets a type of recognition, and hence, increases his job-satisfaction. Promotions increases employee's perceptions of the quality of their job and thereby enhance both their satisfy action and commitment.

\section{- Organizational commitment}

Organizational commitment is an important organizational subjects as committed employees benefit their organizations, and displays various favorable organizational outcomes. Maintenance of organizational commitment is a viable organizational goal. A variety of factors have been identified that shape organizational commitment. Such factors include job- related factors, employment opportunities, personal characteristics, and positive relationships.

\section{Work Environment}

Work environment involves all the aspects which act and react on the body and mind of an employee. Under organizational psychology, the physical, mental and social environment where employees are working together and there work to be analyzed for better effectiveness and increase productivity. The major purpose is to generate an environment which ensures the 
ultimate ease of effort and eliminates all the causes of frustration, anxiety and worry. If the environment is congenial, fatigue, monotony and boredom are minimized and work performance can be maximized.

\section{Elements of Work Environment}

1) Physical Environment

- Ventilation \& temperature:

- Noise

- Infrastructure \& Interior

- Amenities

2) Social Environment: social environment denotes to the cluster to which an employees to be appropriate. Within an enormous ceremonial work group employees from casual cluster in their personal. Employees develop an intellect of belonging to their cluster. The standards and privileged of the cluster impact significantly the attitude and behaviour of individual employees.

\section{Characteristics of Work Environment}

1) Apparent and Open Communication: In essence, it addresses the employees feel that they are appropriate in the organization. However it is necessary for staff to deliberate the organization's philosophy, mission and values.

2) Stability of Work-Life: There has to some sort of balance between work and personal life. In general having the sense of balance will improve job satisfaction among employees.

3) Impartiality: Employees need to identify that they are being impartially rewarded established on their performance. Impartiality means that the consequences of performance are resolute by the quantity and quality of the performance.

4) Consistency: Consistency means predictability. Subordinates want to know how their supervisor will react in a given situation. According to management studies consistency is a single most effective standard to establish with your own leadership.

\section{Promotion}

Promotion is one of the sensitive issues in every employee's life. Through promotion an employee get recognition of his or her performance and is motivated to continue in this way. According to Pigors and Myers, promotion is an advancement of an employee to better job, better in terms of greater responsibilities, more prestige or status, greater skill and specially increased rate of salary.

From another viewpoint, promotion is a movement to a position in which responsibility and prestige are increased. Promotion involves an increase in rank ordinarily. Again promotion is regarded as a change that results in higher earnings; but increased earnings are essential in a promotion. A promotion can be both horizontal and vertical. In horizontal promotion, an employee is promoted from lower level to higher level where as on the other hand, in vertical promotion an employee is promoted from lower level to higher level or sustains at the same level with more responsibilities only by changing his or her department. 
Whatever the promotion is, from organizational perspective, promotion provides an employee higher position and salary, respect, facilities etc. From psychological point of view promotion satisfies the demand both for job security and career development of an employee. Sometimes dry promotion is taken place without increasing employee's salary which cannot reduce the attractiveness of promotion to an employee because these promotions give satisfaction to the promoted employees in the form of feeling of pride and wellbeing or bring greater esteem and higher status.

\section{Review of Literature}

According to Dr. M.G.Varshney and Sangeeta Malpani (Feb2014) have been suggested the levels of job satisfaction of SBI employees in udaipur and rajsamand districts and the factors contributing to job satisfaction. Finally the research concluded that dimensions and degree of job satisfaction of bank employees of udaipur and rajsamand are not uniform and there is no single dimension.

Ankita Sharmaet al., (Aug. 2014) investigated the level of job satisfaction of public sector bank employees in district Hamirpur. The research concluded that increase in level of salary of employees, performance appraisal system, promotional strategies, training and development program improves overall satisfaction of employees.

According to Vrinda N.N. and Nisha Ann Jacob (Feb. 2015) studied the impact of job satisfaction on job performance. This study investigated the most satisfying event of an employee in the job, why employees stay and leave the organization and also the determination of job satisfaction. The study concluded that job satisfaction and performance was found to be even higher for professional jobs than for less complex jobs.

\section{Research Methodology}

Sources of data : Primary and secondary data

Tool of data collection : Questionnaire method

Data collection period : One month

Sample size : $: 50$

Sampling method : : Simple Random sampling

Stastistical tools $\quad$ : Percentage method, quartile analysis

Study area : Indian Bank in vellore city

\section{Analysis and Interpretation}

\section{Demographic Analysis}

The respondents profile with respect to Age, Gender and Marital Status is analysed and delineated below.

Age:

The Age of respondents is tabulated in Table 1. 
Table 1: Age distribution of Respondents

\begin{tabular}{|l|l|l|}
\hline \multicolumn{1}{|c|}{ Experience in Years } & Frequency & Percent \\
\hline$<30$ years & 12 & 24.0 \\
\hline $30-40$ years & 15 & 30.0 \\
\hline $41-50$ years & 13 & 26.0 \\
\hline$>50$ years & 10 & 20.0 \\
\hline Total & 50 & 100.0 \\
\hline
\end{tabular}

The data indicates that majority (30\%) of respondents are in $30-40$ years age group. The lowest percentage of respondents $(10 \%)$ is above 50 years old.

\section{Gender:}

The gender of respondents is analysed and presented in table 2:

Table 2: Gender distribution of Respondents

\begin{tabular}{|l|l|l|}
\hline \multicolumn{1}{|c|}{ Gender } & Frequency & \multicolumn{1}{c|}{ Percent } \\
\hline Male & 40 & 80.0 \\
\hline Female & 10 & 20.0 \\
\hline Total & 50 & 100.0 \\
\hline
\end{tabular}

It can be inferred from Table 2 that most respondents are male and form $80 \%$ of respondents. Female respondents form the rest $20 \%$.

\section{Marital Status:}

The Marital status of respondents is analysed and presented in table 3:

Table 3: Marital Status distribution of Respondents

\begin{tabular}{|l|l|l|}
\hline Marital Status & Frequency & Percent \\
\hline Married & 16 & 32.0 \\
\hline Unmarried & 20 & 40.0 \\
\hline Widow & 4 & 8.0 \\
\hline Widower & 5 & 10.0 \\
\hline Separated & 5 & 10.0 \\
\hline Total & 50 & 100.0 \\
\hline
\end{tabular}

Majority of respondents are unmarried. $32 \%$ are married, widows form $8 \%$ of respondents. Widowers and 'Separated' are 10\% each.

\section{Residence, Qualification and Designation:}

The analysis of respondents profile with respect to their place of residence, Educational Qualification and work designation in Indian bank was carried out. 
The residential area of respondents is analysed and presented in table 4:

Table 4: Residence distribution of Respondents

\begin{tabular}{|l|l|l|}
\hline \multicolumn{1}{|c|}{ Residence Area } & Frequency & Percent \\
\hline Rural & 22 & 44.0 \\
\hline Urban & 21 & 42.0 \\
\hline Semi Urban & 7 & 14.0 \\
\hline Total & 50 & 100.0 \\
\hline
\end{tabular}

Majority of respondents are in rural area, followed by $42 \%$ who live in Urban area. $7 \%$ respondents live in rural area.

The Educational Qualification of respondents of respondents is analysed and presented in table 5:

Table 5: Educational Qualification of Respondents

\begin{tabular}{|l|l|l|}
\hline \multicolumn{1}{|c|}{ Educational Qualification } & Frequency & Percent \\
\hline SSLC & 9 & 18.0 \\
\hline+2 & 11 & 22.0 \\
\hline Graduate & 10 & 20.0 \\
\hline PG & 12 & 24.0 \\
\hline Others & 8 & 16.0 \\
\hline Total & 50 & 100.0 \\
\hline
\end{tabular}

Majority of respondents are Post Graduates, followed by $22 \%$ of ' +2 ' educated respondents. Respondents holding 'Other' qualifications form lowest $8 \%$ of respondents.

The Designation of respondents is analysed and tabulated in table 6:

Table 6: Designation of Respondents

\begin{tabular}{|l|l|l|}
\hline \multicolumn{1}{|c|}{ Designation } & Frequency & \multicolumn{1}{c|}{ Percent } \\
\hline Officer & 7 & 14.0 \\
\hline Clerk & 6 & 12.0 \\
\hline Sub Staff & 12 & 24.0 \\
\hline Accountant & 13 & 26.0 \\
\hline Cashier & 6 & 12.0 \\
\hline Manager & 6 & 12.0 \\
\hline Total & 50 & 100.0 \\
\hline
\end{tabular}

Majority (26\%) of respondents are Accountants, followed by $24 \%$ sub staffs and $14 \%$ officers. Clerk, Cashiers and Managers constitute $12 \%$ each. 


\section{Job Satisfaction}

Job Satisfaction is measured using two parameters - Work condition at bank and Promotion in bank. The responses given to questions under these two parameters are scored and the total score is used to analyse if respondents are Highly Satisfied, Satisfied or Not Satisfied. The scores given to response 'Strongly disagree' is 1, to 'Disagree' is 2, 3 for 'Neutral', 4 for 'Agree' and 5 for 'Strongly agree'. The scores are summed and Quartile analysis is carried out. The result of Quartile analysis is presented in Table 7

Table 7: Quartile Analysis

\begin{tabular}{|l|l|l|}
\hline Percentiles & Work Condition & Promotion \\
\hline 25 & 16 & 13 \\
\hline 50 & 20 & 15.5 \\
\hline 75 & 22 & 18 \\
\hline
\end{tabular}

Based on quartile analysis, the satisfaction of respondents is classified into three groups. Respondents whose total score was equal to or greater than 22 for Work Condition, and respondents whose total score was equal to or greater than 18 for Promotion are classified into 'Highly Satisfied' Group. Those whose Work Condition total score was equal to or below 16 are considered ' Not Satisfied'. Respondents whose Promotion total score was equal to or below 16 are considered 'Not Satisfied'. The rest are classified as 'Satisfied'.

\section{Designation and Job satisfaction:}

Analysis with respect to designation of respondents is tabulated in Table 8 below

Table 8: Designation Wise Satisfaction

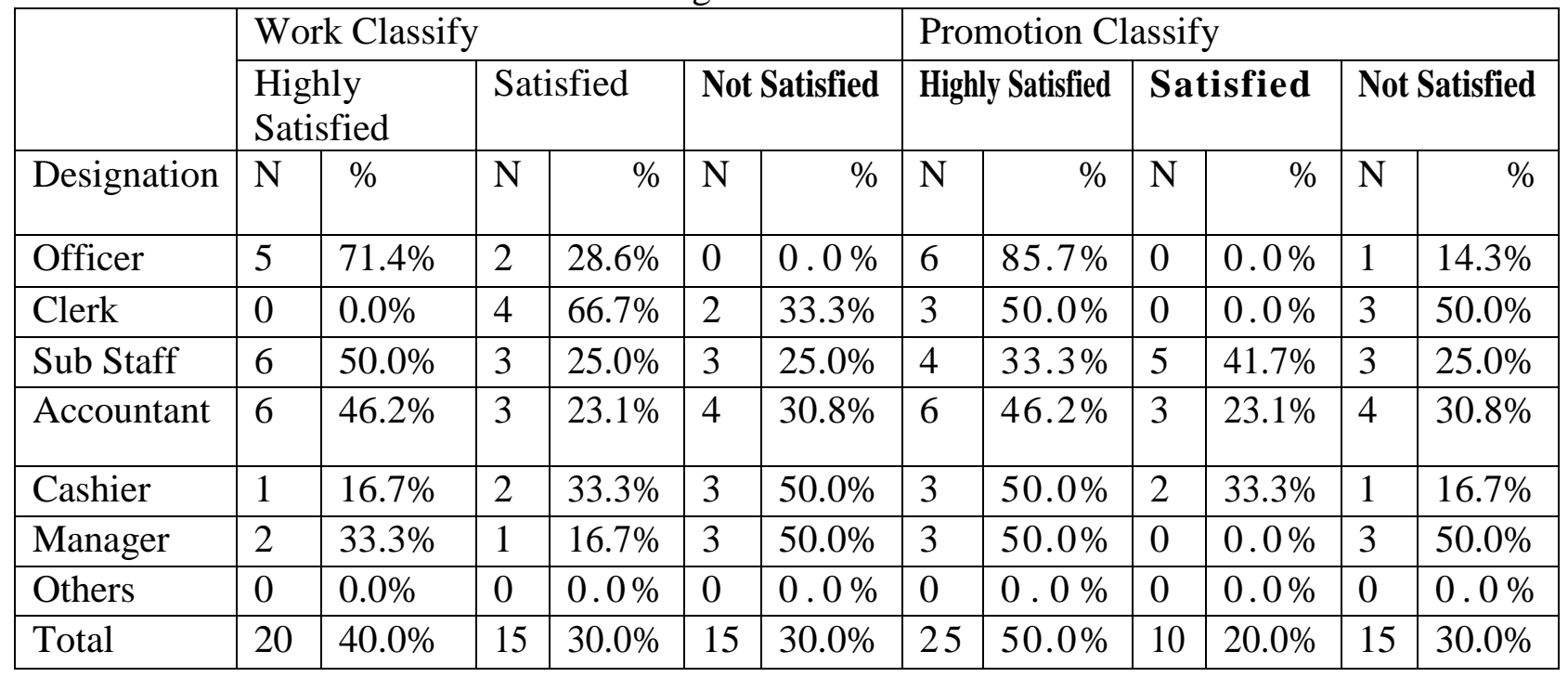

N= Number of Respondents

From table above it can be noted that $71.4 \%$ of Officer are highly satisfied, $50 \%$ of Sub Staff, $46.2 \%$ of Accountant, $16.7 \%$ of Cashier ,33.3\% of Manager are highly satisfied. Majority of Officers are Highly Satisfied. Dissatisfaction level is highest among Cashiers and Managers. Both category of designation have 50\% 'Not satisfied' respondents. Over all $40 \%$ respondents 
are highly satisfied with their work condition at Indian banks and 30\% are not satisfied. As far as Promotion related factors are concerned, 50\% are highly satisfied, $20 \%$ are satisfied and 30\% are not satisfied. The Officers form largest percentage of 'Highly Satisfied' respondents. $50 \%$ Clerks and $50 \%$ Officers are not satisfied with promotion. 10\% more respondents are 'highly satisfied' with promotion than with work condition at Indian bank.

\section{Experience and Job satisfaction:}

Analysis of Job Satisfaction with respect to work experience of respondents is tabulated in Table below

Table 9: Experience Wise Job Satisfaction

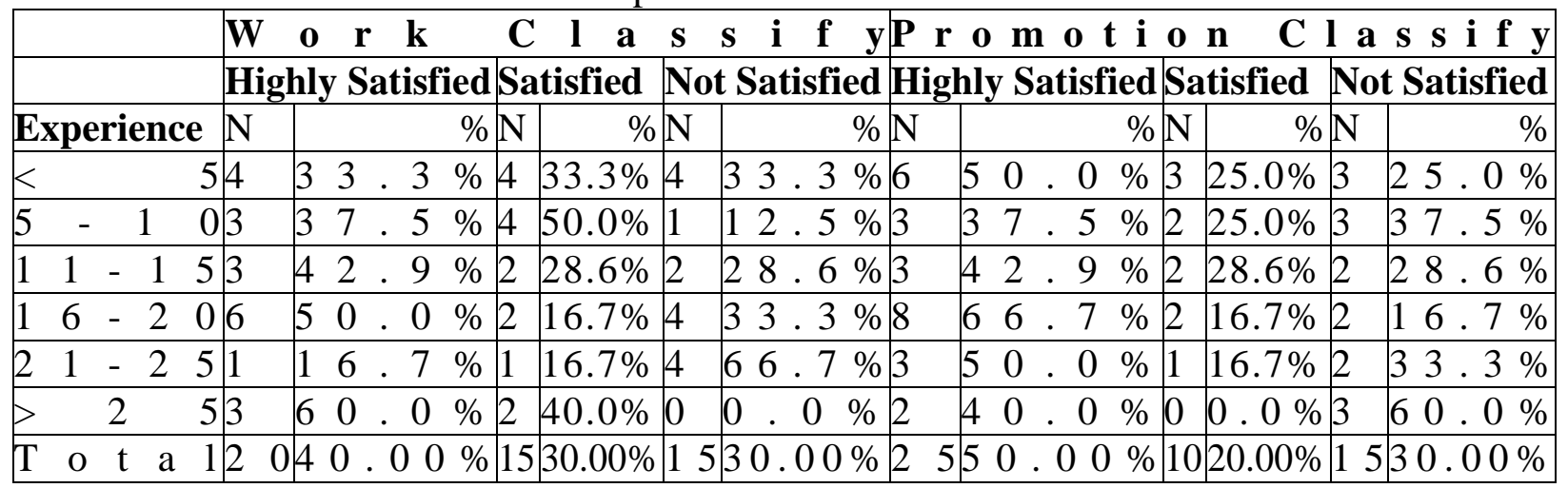

\section{$\mathrm{N}=$ Number of Respondents}

Data from table above indicates that $33.3 \%$ of respondents with $<5$ experience are highly satisfied, $42.9 \%$ of respondents with 11-15 years' experience ,50\% of respondents with 16-20 years' experience, $16.7 \%$ respondents with experience of $21-25$ year and $60 \%$ of respondents with $>25$ years' experience are highly satisfied with work condition in Indian bank. Total 40\% respondents are highly satisfied with Work condition. The Highest Satisfaction level is found among respondents with above 25 years' experience. Largest numbers of unsatisfied respondents are in 21-25 years' experience group.

Data from table above indicates that $33.3 \%$ of respondents with $<5$ experience are satisfied,50\% of respondents with 5-10 years' experience, $28.6 \%$ of respondents with 11-15 years' experience , $16.7 \%$ respondents with experience of 16-20 year and 21-15 years' experience are satisfied. $40 \%$ of respondents with $>25$ years' experience are satisfied with work condition in Indian bank. Total $15 \%$ respondents are highly satisfied with Work condition. When it comes to promotion, $50 \%$ of respondents are Highly Satisfied, 20\% are satisfied and 30\% are not satisfied. The Highest Satisfaction level is found among respondents with $16-20$ years' experience. Largest number of Unsatisfied respondents are $>25$ years' experience group.

\section{Educational Qualification and Job satisfaction:}

Analysis of Job Satisfaction with respect to educational qualification of respondents is tabulated in Table below 
Table 10: Educational Qualification and Job Satisfaction

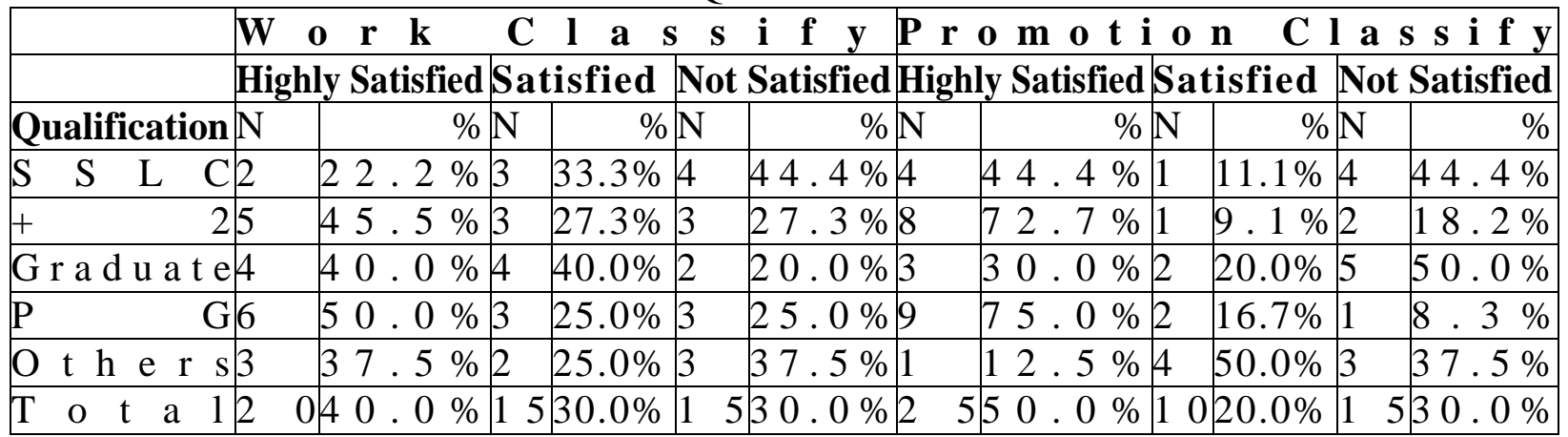

$\mathrm{N}=$ Number of Respondents

From table above it can be noted that $22.2 \%$ of respondents with SSLC education are highly satisfied, $45.5 \%$ of respondents with +2 education, $40 \%$ of respondents with Graduate degree, $50 \%$ of PG and $37.5 \%$ of Others degree holders are highly satisfied. Maximum 'Highly Satisfied' respondents are Post Graduate. The most dissatisfied respondents have SSLC education.

In case of promotion in Indian Bank, maximum 'Highly Satisfied' respondents are Post Graduate while most unsatisfied respondents are Graduates.

\section{Major Findings}

Based on analysis of data, the major findings of the study are

- As far as working condition is concerned, overall $40 \%$ respondents are highly satisfied with their work condition at Indian banks and $30 \%$ are not satisfied.

- As far as Promotion related factors are concerned, 50\% are highly satisfied, $20 \%$ are satisfied and $30 \%$ are not satisfied. $10 \%$ more respondents are 'highly satisfied' with promotion than with work condition at Indian bank.

- When designation is taken into consideration, it is found that $71.4 \%$ of Officer are highly satisfied, $50 \%$ of Sub Staff, $46.2 \%$ of Accountant, $16.7 \%$ of Cashier, $33.3 \%$ of Manager are highly satisfied.

- Majority of Officers are Highly Satisfied with work condition. Dissatisfaction level related to work condition is highest among Cashiers and Managers. Both category of designation have $50 \%$ 'Not satisfied' respondents.

- The Officers form largest percentage of 'Highly Satisfied' respondents as far as promotion is concerned. $50 \%$ Clerks and $50 \%$ Officers are not satisfied with promotion.

- Analysis of experience and Work condition showed that the highest Satisfaction level is found among respondents with above 25 years' experience. Largest numbers of unsatisfied respondents are in 21-25 years' experience group.

- Analysis of experience and Promotion indicates that the highest Satisfaction level is found among respondents with 16 -20 years' experience. Largest number of Unsatisfied respondents are $>25$ years' experience group.

- As far as Work condition is concerned, maximum 'Highly Satisfied' respondents are Post Graduates. The most dissatisfied respondents have SSLC education. 
- In case of promotion in Indian Bank, maximum 'Highly Satisfied' respondents are Post Graduate while most unsatisfied respondents are Graduates.

\section{Suggestions}

- Working condition in Indian Bank needs to be improved as $30 \%$ are not satisfied. Feedback from $30 \%$ of the dissatisfied respondents will help in focusing on areas of improvement in work condition.

- Suggestions to improve work condition can also be taken from $40 \%$ of respondents who are highly satisfied with work condition. The difference in perception between those who are Highly satisfied and those who are dissatisfied will help the personnel manager to decide on course of action. If the difference is entirely perceptual, the dissatisfied respondents can be satisfied by reducing their perceptual dissonance else physical enhancements to work place can be carried out.

- Cashiers and Managers form the largest group of respondents which are dissatisfied with work condition hence special concentration should be given to improve their work condition by getting feedback specifically from them

- Majority of Officers are highly satisfied with work condition. Personnel managers can seek to maintain the satisfaction level by enhancing the positive aspects of Manager's working environment.

- Respondents with above 25 yearsof work experience are highly satisfied with their work conditions but they are Unsatisfied with promotion. This aspect needs to be examined by the personnel manager of the bank. If there is hindrance in promotion, it has to be taken up on priority basis as highly experienced respondents who don't get proper promotion will be disgruntled with their job. It also sets a bad precedence for younger employees of the bank.

- Most of the SSLC passed respondents are not satisfied with work condition. This is probably due to them occupying lower position in the bank. Personnel manager can take step to improve basic working conditions of employees in lower grade .

- Post Graduates are highly satisfied with both work condition and promotion hence no special attention is required to improve the job satisfaction among them.

- Most of the graduates are dissatisfied with promotion. It is suggested that proper internal career guidance can be arranged for Graduates in bank to show and guide them through various path of promotions.

\section{Conclusion}

This study concentrated on Job Satisfaction of Indian Bank employees and analysed the Job satisfaction's two main parameters - Work condition at bank and Promotion in bank. Job satisfaction was analysed threadbare with respect to designation, work experience and educational qualification of respondents. The insights gained by this differential analysis have brought out areas of improvement and has given a clear path to personnel managers to improve Job Satisfaction among Indian Bank employees. The study has a broader appeal and can be extended to other banks and financial institutions to gain helpful insights into Job Satisfaction of the employees. 


\section{References}

[1] Ankita Sharma \& Dr. Manish Khanna " Job satisfaction among bank employees- A study on district hamirpur (H. P) published in International Journal of science, Environment. Vol-3, No.4, 2014- ISSN:2278-3687, p.p. 1582-1591. (Aug-2014).

[2] D.Yoder, Personnel Management and Industrial Relations. Prentice Hall India Private Limites, New Delhi, 1972.

[3] Dr. M.G. Varshney, Sangeetamalpani (Feb-2014) "Paper on job satisfaction of sbi employees" published in IOSR-JBM, E-ISSN: 2278-487X, p-ISSN:2319-7668. Vol-16, Issue 1. P.p. 44-52.

[4] Golden, S. A. R. (2017). Recent Research in Social Sciences \& Humanities. EduPedia Publications (P) Ltd.

[5] Golden, S. A. R., \& Regi, S. B. (2015). Satisfaction of Customers towards User Friendly Technological Services offered by Public and Private Sector banks at Palayamkottai, Tirunelveli District. International Journal of Research, 2(3), 775-787.

[6] Golden, S. A. R., Regi, S. B., \& Franco, C. E. (2014). A study on Impact of Information Technology (IT) in Modern Banking Sector. Golden Research Thoughts, 3(11), 1.

[7] Human Resource and Personnel Management- K.Aswathappa.

[8] Human Resource Management- Book of Dr. C.B.Gupta published by Sultan Chand\& Sons.

[9] Personnel Management and Industrial Relation- P.C. Tripathi.

[10] Pigors, Paul, C.A. Myers and F.T. Malm, Management of Human Resources. McGraw Hill Book Company, New York, 1971.

[11] Regi, S. B., \& Golden, S. A. R. (2014). Attitude of Rural People Towards Technology Inclusion In Banking Services At Tirunelveli District. IGJAE-Indo Global Journal Of Applied Management Science, 2 (2).

[12] Regi, S. B., \& Golden, S. A. R. (2014). Customer Preference Towards Innovative Banking Practices Available In State Bank Of India At Palayamkottai. Sankhya International Journal Of Management And Technology, 3 (11 (A)), 31, 33.

[13] Regi, S. B., \& Golden, S. A. R. (2014). Customer Preference Towards E-Channels Provided By State Of Bank Of India.

[14] Vrinda NN, Nisha ANN Jacob "The Impact on job satisfaction on job performance" published in International Journal in commerce, IT \& social sciences, vol-2, Issue-2 (Feb-2015) ISSN:33945702. P.p. 27-37.

[15] www.google.com

[16] www.corporate information.com. 